\title{
Effect of non-edible oils on population buildup of acarid mite, Tyrophagus putrescentiae Schrank on stored groundnut
}

Rinkikumari Chauhan and Abhishek Shukla*

Department of Entomology, N.M. College of Agriculture, Navsari Agricultural University, Navsari (Gujarat) India

\section{ARITCLE INFO}

Received : 24.07 .2019

Revised : 19.08 .2019

Accepted : 05.09.2019

KEY WORDS :

Non-edible oils, Population build-up, Groundnut, Tyrophagus putrescentiae Schrank

*Corresponding author:

Email : abhishekshukla@nau.in

\begin{abstract}
The effects of different non-edibles oils were tested in terms of population build-up of acarid mite, T. putrescentiae at 30,60 and 90 days interval. The mite population, 30 days after treatment was noticed in control (331.00 mites). In Neem oil treated groundnut at $0.50 \mathrm{ml} / \mathrm{kg}, 1.00 \mathrm{ml} / \mathrm{kg}$ and $2.00 \mathrm{ml} / \mathrm{kg}$ concentrations, and the population was 164.33 , 103.33 and 85.67 mites. Further, 60 days after treatment, the maximum mite population was noticed in case of untreated control (814.87 mites). In Neem oil and eucalyptus oil treated groundnut seeds at $0.50 \mathrm{ml} / \mathrm{kg}, 1.00 \mathrm{ml} / \mathrm{kg}$ and $2.00 \mathrm{ml} / \mathrm{kg}$ concentration, the mite population was zero. Likewise, 90 days after mixing of different oils in groundnut seeds, the maximum mite population was recorded in control (1055.67 mites). In Neem oil treated groundnut seeds, the mite population was zero and it was also zero in case of eucalyptus oil treated groundnut seeds at all the three concentrations. Among all the non-edible oils treated groundnut seeds, the mite population was highest in alsi oil at $0.50 \mathrm{ml} / \mathrm{kg}$ concentration ( 867.17 mites).
\end{abstract}

How to view point the article : Chauhan, Rinkikumari and Shukla, Abhishek (2019). Effect of non-edible oils on population buildup of acarid mite, Tyrophagus putrescentiae Schrank on stored groundnut. Internat. J. Plant Protec., 12(2) : 98-104, DOI : 10.15740/HAS/IJPP/12.2/98-104, Copyright@ 2019: Hind Agri-Horticultural Society. 